\title{
Application of Tegeran (Maclura cochinchinensis) bark as natural tanning agent for the quality of tilapia fish skin
}

\author{
Gresy Griyanitasari*, Iwan Fajar Pahlawan, Umi Reza Lestari \\ Center for Leather, Rubber and Plastics, Ministry of Industry, Jl. Sokonandi No. 9, Yogyakarta 55166, Indonesia \\ *Corresponding author. Tel. +62274512929, Fax. +62274563655 \\ E-mail: gresygriyanitasari@gmail.com
}

Submitted: 13 August 2019

Revised: 26 November 2019

Accepted: 27 November 2019

\begin{abstract}
Chrome is a tanning material that is very harmful to the environment hence its role is being replaced with vegetable tanning materials. One of the natural ingredients that contain tannin is Tegeran (M. cochinchinensis) wood. The aim of this study was to determine the effect of $M$. cochinchinensis as natural tanning agent for tilapia fish skin. Tannin contained in the M. cochinchinensis was being extracted using three solvents: water, ethanol, and water-ethanol (1:1). The composition of the material and the solvent was 1:4. It was heated in the waterbath at temperature $70{ }^{\circ} \mathrm{C}$ for 3 hours. The results showed that the use of $M$. cochinchinensis as natural tanning agent could at once gave unique color to the tanned fish skin. The average of shrinkage temperature was $78.11^{\circ} \mathrm{C}$. Leather tanned with M. cochinchinensis that was extracted with water showed higher value of tensile strength and tear strength than those with ethanol and water-ethanol.
\end{abstract}

Keywords: leather tanning, M. cochinchinensis, tannin extraction, tegeran wood, tilapia.

\section{INTRODUCTION}

Leather industry needs various chemicals for the tanning process to convert skins and hides, byproducts of the meat industry, into leather (Gil et al., 2012; Onem et al., 2015; Teng et al., 2016; van Gerven et al., 2016). The most common tanning agent used in leather industry is chromium sulphate base (Geier \& Lessmann, 2012) because it can deliver soft leather and reduce leather tanning cost. Aside from chromium, other chemicals usually used in tannery are aluminium, formaldehyde, and synthetic tanning.

Whilst tannery is an important industry for environtment because it utilizes slaughterhouse wastes, this industry also produces pollutants to the environment (Gil et al., 2012; Cao et al., 2017), particularly because chrome utilization can harm the environment. In chrome tanning process, $55-65 \%$ of chrome is not absorbed in the leather and become liquid wastes (Covington, 2009). The increase of awareness against environment and health issues nowadays (Aslan, 2009; Selvi et al., 2013; Krishnamoorthy et al., 2013) makes tanneries compete in making environmentally friendly products.

Various vegetable tanning agents commonly used in tannery are mimosa, quebracho, chestnuts, divi-divi, and gambier. One of natural materials known as natural dyes in batik processing and commonly found in Indonesia is $M$. cochinchinensis. The plant has several names, such as Tegeran, Cudrania javanensis, M. javanica, Cudraina cochinchinensis, Kayu Kuning, Soga Tegeran, Kederang (Malaysia), and Kokompusa (Philippines) (Lemmens \& WulijarniSoetjipto, 1991). M. cochinchinensis has a rough, gummy, and spiny stem with brownish color (Atika \& Salma, 2017). As a dyeing agent, $M$. cochinchinensis produces yellow or yellowish green color.

Although M. cochinchinensis is commonly used as a coloring agent, no studies have shown that M. cochinchinensis can be used for leather tanning while study about its tannin content is very limited. Hence, before starting this research, $M$. cochinchinensis have extracted with water. 
The result showed that the tannin content of $M$. cochinchinensis was $11.46 \%$. This value is lower than the tannin content of mimosa (71-72.5\%) (Kasmudjiastuti, 2014) which is commonly used for vegetable leather tanning. However, $M$. cochinchinensis produces a distinctive color that other dyeing agents do not have. Its use as tanning agent could at once give color to the leather, so the dyeing process can be eliminated.

Tannin contained in $M$. cochinchinensis has to be extracted in order to be used as leather tanning agent. Tannin extract derived from plants has been widely used in leather production in the world (Kardel et al., 2013). Therefore, currently, there is an increasing demand for the development of effective and efficient techniques of natural material extraction (Sae-leaw et al., 2013). Various kinds of extraction techniques are carried out to gain optimum extracts. The extraction result depends on the solvent used, method, time, and extraction temperature, as well as the composition and physical characteristics of the sample, such as texture (Tan \& Kassim, 2011).

In recent years, consumer preferences has been changed into non-conventional leather, such as tilapia fish skin (Oreochromis niloticus). As a waste of fillet industry, tilapia fish skin is not optimally utilized yet, because its utilization is limited into skin crackers with low economic value. Tilapia fish skin through tanning process can increase its value into fish skin product that has beautiful motif and similar quality to reptile skin. Hence, the aim of this study was to determine the effect of $M$. cochinchinensis wood extract as vegetable tanning agent.

\section{MATERIALS AND METHODS Materials}

The material used in this study was Tegeran (M. cochinchinensis) bark obtained from Prawoto Shop, Yogyakarta. Tilapia fish skin used was in dry condition as industrial wastes of PT. Aquafarm Nusantara, Central Java, Indonesia. The chemicals used were ethanol $70 \%, \mathrm{KAl}\left(\mathrm{SO}_{4}\right)_{2} \cdot 12 \mathrm{H}_{2} \mathrm{O}$, wetting agent, $\mathrm{Na}_{2} \mathrm{~S}, \mathrm{Ca}(\mathrm{OH})_{2},\left(\mathrm{NH}_{4}\right)_{2} \mathrm{SO}_{4}, \mathrm{NH}_{4} \mathrm{Cl}$, bating agent, degreasing agent, $\mathrm{HCOOH}, \mathrm{H}_{2} \mathrm{SO}_{4}$ $\mathrm{NaHCO}_{3}, \mathrm{Al}_{2}\left(\mathrm{SO}_{4}\right)_{3}$, fish oil, synthetic oil, and Sincal DR.

\section{Equipments}

The equipment used in this study were hammer, $100 \mathrm{ml}$ beaker glass, $600 \mathrm{ml}$ beaker glass, measuring cylinder, Memmert waterbath, analytical scale, digital scale, $150 \mu \mathrm{m}$ filter paper, experimental tanning drums, fleshing knives, easel, sculpting tools, staking tools, $\mathrm{pH}$ paper, plastic cups, and shrinkage temperature tester.

\section{Methods \\ Preparation of $M$. cochincinensis}

Dried M. cochincinensis wood was reduced in size using hammer. The solvent to extract the wood was varied into three types, i.e. water (NT-a), ethanol (NT-e), and water-ethanol (NTae). Water-ethanol solvent was prepared using 1:1 ratio. Then, 10 gram of wood was added by 40 $\mathrm{ml}$ of each solvent and heated in waterbath for 3 hours at $70{ }^{\circ} \mathrm{C}$ temperature. The extraction yield was filtered through two filtration stages, gauze filtration continued with filtration using $150 \mu \mathrm{m}$ filter paper. Furthermore, the M. cochincinensis extract was stored for a day before applied for tanning operation.

\section{Tanning procedure}

Three types of $M$. cochinchinensis extract were immediately applied to tilapia fish skin through tanning process with three replications. The codes used were NT-e; NT-a; and NT-ae which indicate the fish skins were tanned with $M$. cochinchinensis extracted in ethanol, water, and water-ethanol. The tanning procedure was carried out through several stages according to the tanning process by Pahlawan and Kasmudjiastuti (2012) with several modifications as showed in Table 1. Percentage of chemicals used was based on the weight of the skins (w/w).

After the tanned fish skin was hung, it was toggled for a day and stacked. Then, $\mathrm{HCOOH}$ and $\mathrm{H}_{2} \mathrm{SO}_{4}$ were added $3 \times 15$ minutes that meant the chemicals were added step by step for every 15 minutes.

\section{Testing of tanned tilapia skin quality}

Quality assessment was conducted on physical quality of tilapia fish skin leather that has been tanned using $M$. cochinchinensis extract. The tests carried out were analysis of variance (anova), shrinkage temperature tensile strength and elongation tests based on the testing method in SNI 06-1795-1990 (BSN, 1990), as well as tear strength, and total ash content using the testing method in accordance with SNI 06-1794-1990 and SNI 06-0645-1989 (BSN, 1989) consecutively. 
Table 1. Tilapia fish skin tanning process.

\begin{tabular}{|c|c|c|c|}
\hline Process & Materials & Amount (\%) & Time (minute) \\
\hline Soaking & $\begin{array}{l}\text { Water } \\
\text { Teepol }\end{array}$ & $\begin{array}{c}1000 \\
2\end{array}$ & 240 \\
\hline \multicolumn{4}{|l|}{ Fleshing } \\
\hline \multirow[t]{3}{*}{ Liming } & Water & 1000 & \\
\hline & $\mathrm{Na}_{2} \mathrm{~S}$ & 2 & 30 \\
\hline & $\mathrm{Ca}(\mathrm{OH})_{2}$ & 3 & 60 \\
\hline Deliming, & Water & 300 & \\
\hline Degreasing, & $\left(\mathrm{NH}_{4}\right)_{2} \mathrm{SO}_{4}$ & 2 & 60 \\
\hline \multirow[t]{2}{*}{ Bating } & Teepol & $\begin{array}{l}1 \\
1\end{array}$ & 00 \\
\hline & $\begin{array}{l}\text { Palcobate } \\
\text { Water }\end{array}$ & $\begin{array}{c}1 \\
100\end{array}$ & \\
\hline \multirow{3}{*}{ Pickling } & $\mathrm{NaCl}$ & 10 & 30 \\
\hline & $\mathrm{HCOOH}$ & 1 & $3 \times 15$ \\
\hline & $\mathrm{H}_{2} \mathrm{SO}_{4}$ & 0,5 & $3 \times 15$ \\
\hline \multirow[t]{2}{*}{ Pre-tanning } & $\mathrm{NaHCO}_{3}^{2}$ & 0,5 & $2 \times 15$ \\
\hline & $\mathrm{KAl}\left(\mathrm{SO}_{4}^{3}\right)_{2} \cdot 12 \mathrm{H}_{2} \mathrm{O}$ & 10 & 180 \\
\hline Tanning & M. cochinchinensis & 1.000 & $8 \times 30$, overnight \\
\hline \multirow[t]{5}{*}{ Fatliquoring } & Water $50^{\circ} \mathrm{C}$ & 50 & \\
\hline & Fish oil & $\begin{array}{l}5 \\
4\end{array}$ & 30 \\
\hline & $\begin{array}{l}\text { Synthetic oll } \\
\text { Water } 50^{\circ} \mathrm{C}\end{array}$ & 4 & 30 \\
\hline & $\mathrm{HCOOH}$ & 1 & $3 \times 15$ \\
\hline & Sincal DR & 1 & 15 \\
\hline Washing & Water & 2000 & 10 \\
\hline Hanging & - & - & - \\
\hline
\end{tabular}

\section{RESULTS AND DISCUSSION Shrinkage Temperature}

The anova result showed that the $\mathrm{F}_{\text {count }}$ was greater than the $\mathrm{F}_{\text {table }}$ in the significance of $95 \%$. Thus, it indicates that the solvent of the extraction influenced on the leather's shrinkage temperature. The solvent used to prepare $M$. cochinchinensis would affect the tannin content of the extraction, that the tannin linked to the collagen since shrinkage temperature shows the crosslink degree and hydrothermal stability (Kasmudjiastuti et al., 2015).

M. cochinchinensis wood which was extracted with water, ethanol, and their combination resulted the leather with a shrinkage temperature of $78.19{ }^{\circ} \mathrm{C}$ (Figure 1). This result indicates that $M$. cochinchinensis extract has the ability to provide a good vegetable-tanned leather. Even though, the figure has different result compare to those tanned with gambier as vegetable tanning agent which reached more than $100{ }^{\circ} \mathrm{C}$ (Setiawan et al., 2015). According to BASF (2004), vegetable-tanned leather has shrinkage temperature $70-85{ }^{\circ} \mathrm{C}$. Shrinkage temperature is one of critical point in manufacturing of leather which will determine the quality of leather.
Shrinkage temperature expresses the temperature reached when the leather started to shrink against heat $2{ }^{\circ} \mathrm{C} / \mathrm{min}$. in aqueous medium (Carşote et al., 2016). This study evaluated the crust leather as the object. Different solvents were used for the extraction of $M$. cochinchinensis and then the result were used for tanning. In order to investigate the effect of different solvent of the extract in the tanning process on the shrinkage temperature of tilapia fish crust leather, analysis of variance (anova) is needed.

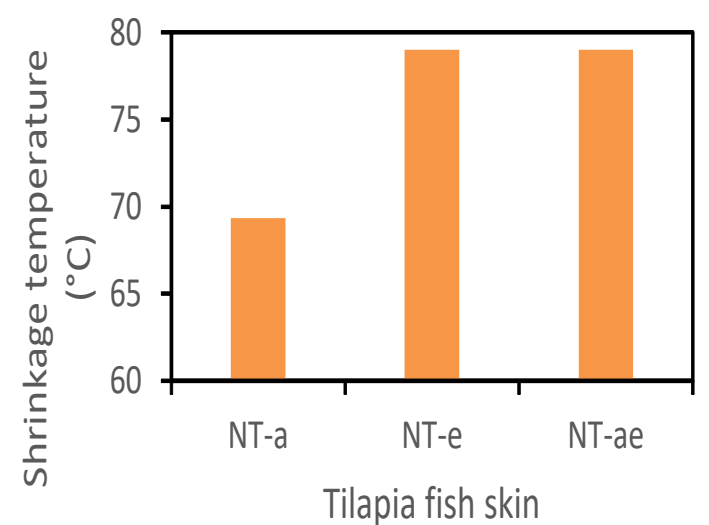

Figure 1. The shrinkage temperature of tannedskin with different tannin extract. 


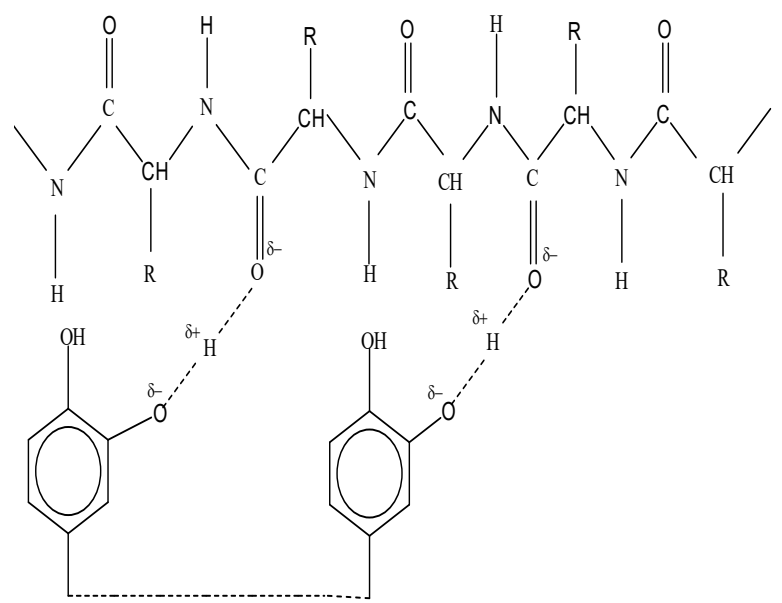

Figure 2. Model of the reaction between plant polyphenol and collagen (Covington, 2009).

Tannin could make a bond with collagen fiber due to its reactive group and has suitable molecule size in binding several collagen fibers at once. The sum of crosslinking bond depends on the molecule size of polyphenol and the amount of $-\mathrm{OH}$ groups (small molecules, $\mathrm{M}<500$, and big molecules, $\mathrm{M}$ $>300$ does not have tanning effect) (Combalia et al., 2016). The reaction between plant polyphenol and collagen of leather is presented in the Figure 2.

The results of shrinkage temperature test showed that the tannin extracted from $M$. cochinchinensis wood with ethanol (NT-e) and a combination of water-ethanol (NT-ae) provided higher shrinkage temperature than that with water (NT-a). Higher tannin bound in the skin fiber resulted in higher shrinkage temperature of tilapia tanned-skin sample.

\section{Tensile Strength}

According to analysis of variant test for tensile strength with $95 \%$ of significance level, the $\mathrm{F}_{\text {count }}$ (12.477) was greater than the $\mathrm{F}_{\text {table }}$ (5.143). It can be concluded that different solvent used in the extraction process has a significant effect on the tensile properties of tilapia fish leather. Tilapia fish skin tanned with $M$. cochinchinensis wood extract, which was extracted with water, ethanol, and the combination of both, has the tensile strength value of $123.21 \mathrm{~kg} / \mathrm{cm}^{2}, 80.46 \mathrm{~kg} / \mathrm{cm}^{2}$, and $79.91 \mathrm{~kg} / \mathrm{cm}^{2}$, respectively (Figure 3 ). The tensile strength value represents the strength of bond between collagen fibers and the tannin. Tilapia fish skin which was tanned with $M$. cochinchinensis wood extract (NT-a) has the greatest tensile properties value.

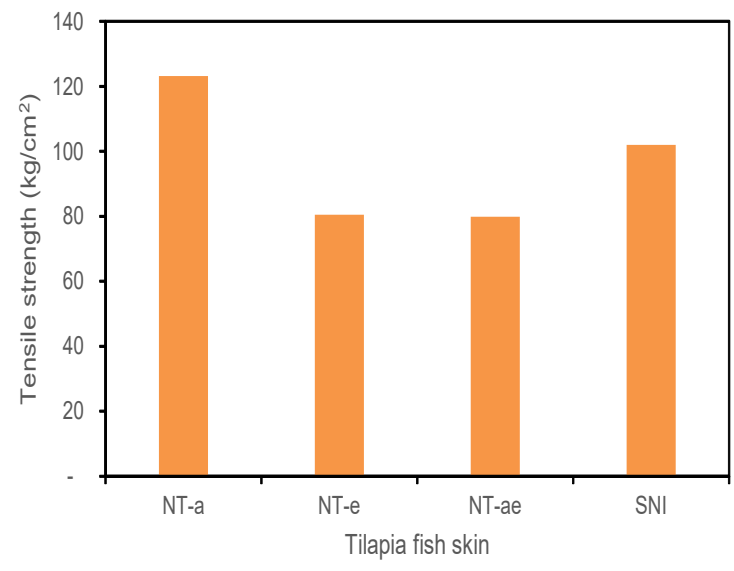

Figure 3. The effect of extraction solvent on tensile strength of the resulted leather.

The result of tensile strength were contradictory with the shrinkage temperature, where the water solvent provided the tannedskin with the highest tensile strength but lowest shrinkage temperature. Tensile properties indicates how strong the maximum torque needed to stretch the leather sample until it breaks into two pieces, and expresses in $\mathrm{kg} / \mathrm{cm}^{2}$ or $\mathrm{N} / \mathrm{cm}^{2}$ unit. According to Kholifah et al. (2014), tensile strength is one of indicator that determine the quality of leather where it represents the bond between hides/skin's collagen fibers and tannin.

Tensile strength of leather could also be influenced by the fat content of the leather. The fat content in leather could increase the tensile strength (Kholifah et al., 2014). Another thing that is also suspected to affect the tensile strength of the leather is the quality of raw skin and process during leather tanning, such as the preserving method of skin, liming process, bating process, fatliquoring, and the process of toggling (Pahlawan \& Kasmudjiastuti, 2012).

According to Indonesian National Standard 06-4586-1998 (BSN, 1998), minimum tear strength of finished leather from freshwater snakes leather tanned with chrome is $102 \mathrm{~kg} /$ $\mathrm{cm}^{2}$ (Figure 3). Hence, only fish skin tanned with $M$. cochinchinensis extracted with water that met the tensile strength requirements. Tanin is polar and can dissolve in polar solvent. High polarity solvent could extract organic compound better than the low ones. Thus, extraction using water could produce less yield but higher quality (Kasmudjiastuti, 2017). 


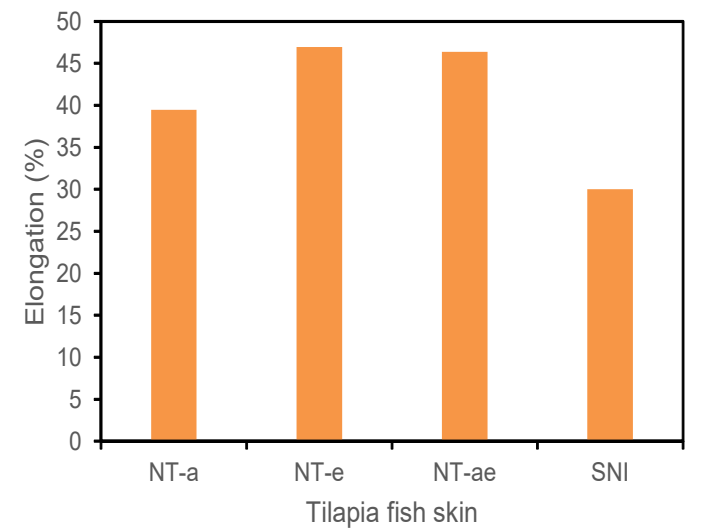

Figure 4. The elongation of resulted leather tanned with different extract.

\section{Elongation at Break}

Leather's elongation is closely related to the elasticity of the resulted leather. The leather becomes soft due to the reduction of elastin during the liming and bating process. The anova test results for elongation with a confidence level of $95 \%$ indicates that $\mathrm{F}_{\text {count }}(0.900)<\mathrm{F}_{\text {table }}$ (5.143). This shows that different solvent used to extract did not significantly affect the elongation of tilapia fish skin. The results of the elongation test in this study showed that $M$. cochinchinensis wood extracted using water, ethanol, and waterethanol has the elongation at $39.49 \%, 46.93 \%$, and $46.37 \%$, respectively (Figure 4).

Indonesia National Standard 06-4586-1998 (BSN, 1998) stated that maximum elongation of finished leather from freshwater snakes leather tanned with chrome is $30 \%$ that all of the samples did not meet the requirements.

\section{Tear Strength}

Tear strength is the maximum limit for the skin to be torn (Kholifah et al., 2014). The anova test results for tear strength with a confidence level of $95 \%$ indicates that $\mathrm{F}_{\text {count }}(7.061)>\mathrm{F}_{\text {table }}(5.143)$. It shows that the solvent used for extraction has significant effect on the tear strength of the tanned fish skin. M. cochinchinensis wood extracted using water, ethanol, and water-ethanol resulted crust leather with tear strength of 20.76, 12.91, and $15.84 \mathrm{~kg} / \mathrm{cm}^{2}$ (Figure 5). Indonesia National Standard 06-4586-1998 (BSN, 1998) stated that minimum tear strength of finished leather from freshwater snakes leather tanned with chrome is 15 only fish skin tanned with water that met the

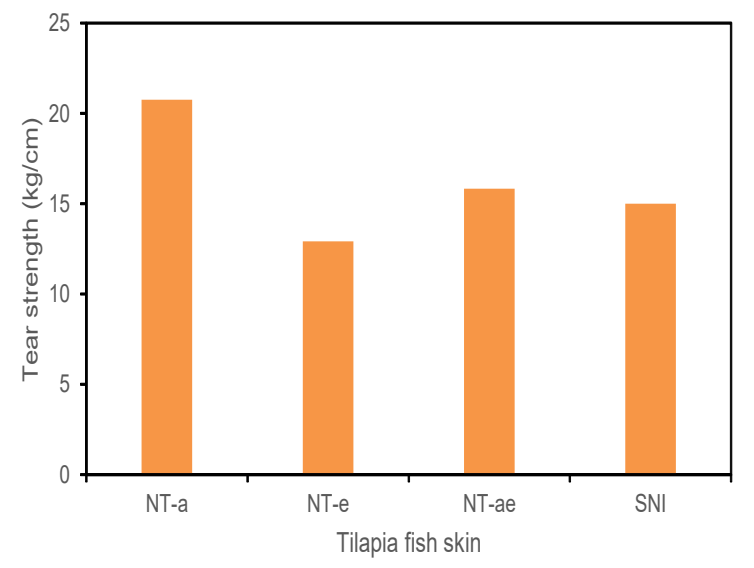

Figure 5. The tear strength of resulted leather with different tannin extract.

requirements. In addition to the tanning agent used in the tanning process, the tear strength can also be affected by the structure of the skin tissue, where the collagen bundle has irregular interwoven.

\section{CONCLUSION}

Tilapiafish skin tanned with M. cochinchinensis extracted with water showed higher value of tensile strength and tear strength than those with ethanol and water-ethanol, whereas tilapia fish skin tanned with $M$. cochinchinensis extracted with ethanol showed higher value of shrinkage temperature and elongation that others. Based on Indonesia National Standard 06-4586-1998 about the quality requirements of freshwater snake skin tanned chrome, only the tilapia fish skin tanned with $M$. cochinchinensis extracted with water that met the tensile strength requirements, while for elongation, all the samples were not met the requirements. The use of M. cochinchinensis as natural tanning agent could at once give unique color to the tanned fish skin. This study is a preliminary research that needs to be improved with another extraction methods of $M$. cochinchinensis or tanning agent combination to meet the better tanned fish skin quality.

\section{ACKNOWLEDGEMENT}

Authors are thankful to the head of Center for Leather, Rubber and Plastics and Ir. Syakir Hasyimi, M.Si for the facilities and testing support during this research.

\section{REFERENCES}

Aslan, A. (2009). Determination of heavy metal 
toxicity of finished leather solid waste. Bulletin of Environmental Contamination and Toxicology, 82(5), 633-638. https://doi.org/10.1007/s00128009-9656-1

Atika, V., \& Salma, I. R. (2017). Kualitas pewarnaan ekstrak kayu Tegeran (Cudrania javanensis) pada batik. Dinamika Kerajinan dan Batik: Majalah Ilmiah, 34(1), 11-18. http://doi.org/10.22322/dkb. v34i1.2642

BSN. (1989). SNI 06-0645-1989: Tanned leather, testing method of chrome oxide content. Jakarta, Indonesia: BSN. (in Indonesia)

BSN. (1990). SNI 06-1795-1990: Testing method of tear strength and elongation of leather. Jakarta, Indonesia: BSN. (in Indonesia)

BSN. (1998). SNI 06-1795-1990: Finished leather from freshwater snakes leather tanned with chrome. Jakarta, Indonesia: BSN. (in Indonesia)

BASF. (2004). Pocket book for the leather technologists (Fourth ed.). Ludwigshafen: BASF Aktiengesellschaft.

Cao, S., Liu, B., Cheng, B., Lu, F., Wang, Y., \& Li, Y. (2017). Mechanisms of $\mathrm{Zn}(\mathrm{II})$ binded to collagen and its effect on the capacity of eco-friendly $\mathrm{Zn}-\mathrm{Cr}$ combination tanning system. Journal of Hazardous Materials, 321, 203-209. https://doi.org/10.1016/j. jhazmat.2016.09.016

Carşote, C., Badea, E., Miu, L., \& Della Gatta, G. (2016). Study of the effect of tannins and animal species on the thermal stability of vegetable leather by differential scanning calorimetry. Journal of Thermal Analysis and Calorimetry, 124(3), 12551266. https://doi.org/10.1007/s10973-016-5344-7

Combalia, F., Morera, J. M., \& Bartolí, E. (2016). Study of several variables in the penetration stage of a vegetable tannage using ultrasound. Journal of Cleaner Production, 125, 314-319. https://doi. org/10.1016/j.jclepro.2016.03.099

Covington, A. D. (2009). Tanning chemistry: The science of leather. Cambridge: Royal Society of Chemistry.

Geier, J., \& Lessmann, H. (2012). Leather industry: Kanerva's occupational dermatology. Berlin: Springer Berlin Heidelberg.

Gil, R. R., Girón, R. P., Lozano, M. S., Ruiz, B., \& Fuente, E. (2012). Pyrolysis of biocollagenic wastes of vegetable tanning. Optimization and kinetic study. Journal of Analytical and Applied Pyrolysis, 98, 129-136. https://doi.org/10.1016/j. jaap.2012.08.010

Kardel, M., Taube, F., Schulz, H., Schutze, W., \& Gierus, M. (2013). Different approaches to evaluate tannin content and structure of selected plant extracts - Review and new aspects. Journal of Applied Botany and Food Quality, 86, 154-166. https://doi.org/10.5073/JABFQ.2013.086.021

Kasmudjiastuti, E. (2014). Karakterisasi kulit kayu tingi (Ceriops tagal) sebagai bahan penyamak nabati. Majalah Kulit, Karet, dan Plastik, 30(2), 71-78. http://doi.org/10.20543/mkkp.v30i2.128

Kasmudjiastuti, E., Sutyasmi, S., \& Widowati, T. P. (2015). Pemanfaatan tanin dari kulit kayu tingi (Ceriops tagal) sebagai bahan penyamak nabati: Pengaruh penambahan alum dan mimosa. Majalah Kulit, Karet, dan Plastik, 31(1), 45-54. http:// dx.doi.org/10.20543/mkkp.v31i1.175

Kasmudjiastuti, E. (2017). Review: Prospek zat warna alam dari ekstrak kayu sebagai bahan untuk pewarnaan kulit. Prosiding Seminar Nasional Kulit, Karet, Dan Plastik Ke-6.

Kholifah, N., Darmanto, Y. S., \& Wijayanti, I. (2014). Perbedaan konsentrasi mimosa pada proses penyamakan terhadap kualitas fisik dan kimia ikan nila (Oreochromis niloticus). Jurnal Pengolahan dan Bioteknologi Hasil Perikanan, 3(4), 113118.

Krishnamoorthy, G., Sadulla, S., Kumar, P., \& Mandal, A. B. (2013). Greener approach to leather tanning process: D-lysine aldehyde as novel tanning agent for chrome-free tanning. Journal of Cleaner Production, 42,277-286. https://doi.org/10.1016/j. jclepro.2012.11.004

Lemmens, R. H. M. J., \& Wulijarni-Soetjipto, N. (1991). Plant resources of South-East Asia No. 3: Dye and tannin-producing plants. Wageningen: Pudoc.

Mengistie, E., Smets, I., \& van Gerven, T. (2016). Ultrasound assisted chrome tanning: Towards a clean leather production technology. Ultrasonics Sonochemistry, 32, 204-212. https://doi. org/10.1016/j.ultsonch.2016.03.002

Onem, E., Gulumser, G., Renner, M., \& Yesil-Celiktas, O. (2015). High pressure vegetable tanning of sheepskins using supercritical carbon dioxide. The Journal of Supercritical Fluids, 104, 259-264. https://doi.org/10.1016/j.supflu.2015.07.002

Pahlawan, I. F., \& Kasmudjiastuti, E. (2012). Pengaruh jumlah minyak terhadap sifat fisis kulit ikan nila (Oreochromis niloticus) untuk bagian atas sepatu. Majalah Kulit, Karet, dan Plastik, 28(2), 105-112. http://doi.org/10.20543/mkkp.v28i2.113

Sae-leaw, T., Benjakul, S., Gokoglu, N., \& Nalinanon, S. (2013). Changes in lipids and fishy odour development in skin from Nile tilapia (Oreochromis niloticus) stored in ice. Food Chemistry, 141(3), 2466-2472. https://doi.org/10.1016/j. foodchem.2013.05.049

Selvi, A. T., Aravindhan, R., Madhan, B., \& Rao, J. R. (2013). Studies on the application of natural dye extract from Bixa orellana seeds for dyeing and finishing of leather. Industrial Crops and Products, 43, 84-86. https://doi.org/10.1016/j. indcrop.2012.07.015

Setiawan, A., Riyadi, P. H., \& Sumardianto. (2015). 
Pengaruh penggunaan gambir (Uncaria gambier) sebagai bahan penyamak pada proses penyamakan kulit terhadap kualitas fisik kulit ikan nila (Oreochromis niloticus). Jurnal Pengolahan dan Bioteknologi Hasil Perikanan, 4(2), 124-132.

Tan, K. W., \& Kassim, M. J. (2011). A correlation study on the phenolic profiles and corrosion inhibition properties of mangrove tannins (Rhizophora apiculata) as affected by extraction solvents. Corrosion Science, 53(2), 569-574. https://doi. org/10.1016/j.corsci.2010.09.065
Teng, B., Jian, X., Gao, Y., \& Chen, W. (2016). Comparison of polyflavonoids in bayberry tanning effluent and commercial bayberry tannin: Prerequisite information for vegetable tanning effluent recycling. Journal of Cleaner Production, 112, 972-979. $\quad$ https://doi.org/10.1016/j. jclepro.2015.09.005 
